\title{
NATURE OF INDUSTRY DAN INEFFECTIVE MONITORING SEBAGAI DETERMINAN TERJADINYA FRAUD DALAM PENYAJIAN LAPORAN KEUANGAN
}

\author{
Nurul Karin Apriyani, Ferdiansyah Ritonga \\ Program Studi Akuntansi \\ STIE STAN Indonesia Mandiri, Jl. Jakarta No. 79 Bandung
}

\begin{abstract}
ABSTRAK
Penelitian ini bertujuan untuk memperoleh bukti empiris mengenai pengaruh nature of industry dan ineffective monitoring terhadap fraud dalam penyajian laporan keuangan. Dalam penelitiaan ini nature of industry sebagai variabel independen memiliki dua proksi yaitu persediaan (inventory) dan piutang (receivable).

Penelitian dilakukan pada perusahaan sektor manufaktur yang terdaftar di Bursa Efek Indonesia pada periode 5 tahun yaitu 2013-2017. Teknik pengambilan sampel yang digunakan adalah purposive sampling. Sampel penelitian ini adalah 110 perusahaan. Metode analisis data yang digunakan adalah regresi logistik.

Hasil penelitian menunjukan bahwa: (1a) nature of industry (inventory) berpengaruh tidak signifikan terhadap fraud dalam penyajian laporan keuangan, (1b) nature of industry (receivable) berpengaruh positif dan signifikan terhadap fraud dalam penyajian laporan keuangan dan (2) ineffective monitoring berpengaruh tidak signifikan terhadap fraud dalam penyajian laporan keuangan.
\end{abstract}

Kata Kunci: Nature of industry, ineffective monitoring, financial reporting fraud

\section{PENDAHULUAN}

Fraud merupakan bahaya laten yang mengancam dunia. Hasil penelitian Association of Certified Fraud Examiners (ACFE) Global menunjukkan bahwa setiap tahun rata-rata 5\% dari pendapatan organisasi menjadi korban fraud. Penelitian yang dilakukan oleh ACFE yang dituangkan dalam laporan Report To The Nation (RTTN) menunjukkan pada tahun 2016 total kerugian yang diakibatkan oleh fraud mencapai USD 6,3 miliar dengan rata-rata kerugian per kasus mencapai lebih dari USD 2,7 juta. Selanjutnya, dari laporannya tersebut ACFE juga menyebutkan bahwa kecurangan yang banyak terjadi adalah penyalahgunaan aset kemudian disusul fraud yang berbentuk korupsi dan kasus yang paling sedikit adalah kecurangan dalam penyajian laporan keuangan (financial statement fraud) yang terjadi kurang dari 10\% dari keseluruhan kasus fraud, namun menyebabkan total kerugian yang sangat banyak dibandingkan jenis fraud lain. Angka tersebut tidak terlalu besar apabila dibandingkan dengan kasus penyalahgunaan aset yang mencapai $83 \%$, tetapi fraud dalam penyajian laporan 
keuangan (financial statement fraud) membawa dampak yang sangat besar. Hal ini menyebabkan informasi yang terkandung di dalamnya tidak valid dan dapat menyesatkan pengguna laporan keuangan dalam mengambil keputusan (Nugraheni dan Triatmoko, 2017).

Langkah untuk memutus rangkaian perilaku fraud didasarkan pada fraud triangle theory oleh Cressey (1953). Kekuatan fraud triangle theory adalah terdapat faktor endogen dan eksogen yang terkait dengan penyebab terjadinya kecurangan. Faktor endogen tersebut adalah tekanan atau motivasi (pressure) dan rasionalisasi (rationalization) pelaku, sedangkan faktor eksogennya adalah kesempatan atau peluang (opportunity) (Utama, et al. 2018). Menurut SAS no. 99, terdapat empat jenis tekanan yang mungkin mengakibatkan kecurangan pada laporan keuangan. Jenis tekanan tersebut adalah financial stability, external pressure, personal financial need, dan financial targets. SAS no. 99 mengklasifikasikan peluang yang mungkin terjadi pada kecurangan laporan keuangan menjadi tiga kategori. Jenis peluang tersebut termasuk nature of industry, ineffective monitoring, dan organizational structure. Rasionalisasi adalah bagian ketiga dari fraud triangle yang paling sulit diukur (Iqbal dan Murtanto, 2016).

Beberapa penelitian sebelumnya melakukan penelitian mengenai faktor yang mempengaruhi fraud dalam penyajian laporan keuangan diantaranya: Susanti dan Yasa (2015) menyatakan bahwa faktor yang mempengaruhi fraud dalam penyajian laporan keuangan adalah financial stability, financial targets dan nature of industry. Suryadi, et al.(2017) financial stability dan external pressure. Aprilia (2017) financial stability, personal financial need dan ineffective monitoring. Pasaribu dan Kharisma (2018) nature of industry. Utama, et al. (2018) financial stability, external pressure, personal financial need, organizational structure dan auditor switching. Sementara itu, Utomo (2018) kebutuhan keuangan pribadi, tekanan eksternal dan ketidakefektifan pengawasan.

Dengan fenomena diatas peneliti tertarik untuk meneliti sifat industri (nature of Industry) dan ketidakefektifan pengawasan (ineffective monitoring) sebagai variabel independen untuk melihat pengaruhnya terhadap fraud dalam penyajian laporan keuangan (financial statement fraud). Karena pada sifat industri (nature of industry), manajer memiliki kesempatan untuk menggunakan perkiraan piutang dan persediaan 
sebagai alat untuk memanipulasi laporan keuangan (Warsidi, et al. 2018). Demikian pula ketidakefektifan pengawasan (ineffective monitoring), SAS No.99 menyatakan bahwa manajer berpeluang untuk melakukan kecurangan laporan keuangan jika tidak terdapat pengawasan yang efektif dalam perusahaan (Aprilia, 2017).

Penelitian ini dilakukan berdasarkan inkonsistensi hasil dari penelitian sebelumnya mengenai pengaruh nature of industry dan ineffective monitoring terhadap fraud dalam penyajian laporan keuangan. Mawarni (2016) menunjukan bahwa nature of industry berpengaruh negatif terhadap kecurangan pelaporan keuangan. Indriani dan Terzaghi (2017) menunjukan bahwa nature of industry berpengaruh positif signifikan terhadap kecurangan laporan keuangan. Warsidi, et al. (2018) menunjukan bahwa nature of industry berpengaruh positif terhadap financial statement fraud. Demikian pula, Pasaribu dan Kharisma (2018) menunjukan bahwa nature of industry berpengaruh positif signifikan terhadap financial statement fraud. Sementara itu, penelitian yang dilakukan oleh Zahro, et al. (2018) menunjukan bahwa nature of industry tidak berpengaruh terhadap financial statement fraud.

Sulkiyah (2016) menunjukan bahwa ineffective monitoring berpengaruh positif signifikan terhadap financial statement fraud. Aprilia (2017) menunjukan bahwa ineffective monitoring berpengaruh positif signifikan terhadap financial statement fraud. Demikian pula Utomo (2018) menunjukan bahwa ketidakefektifan pengawasan berpengaruh negatif signifikan terhadap kecurangan laporan keuangan. Sementara itu, penelitian yang dilakukan oleh Indriani dan Terzaghi (2017) menunjukan bahwa ineffective monitoring tidak berpengaruh terhadap financial statement fraud.

Dalam penelitian ini, peneliti memilih sektor manufaktur yang terdaftar di Bursa Efek Indonesia sebagai objek penelitian, karena sektor manufaktur adalah sektor yang mempunyai jumlah emiten terbesar di BEI. Berdasarkan data survey ACFE menunjukkan bahwa persentase fraud dalam penyajian laporan keuangan paling tinggi terjadi pada sektor manufaktur yaitu sebesar 13,8\% (Susianti dan Yasa, 2015). Selain itu, perusahaan manufaktur rentan terhadap fraud, karena perusahaan manufaktur membutuhkan berbagai macam asumsi dan metode akuntansi dalam menangkap kejadian ekonomi perusahaannya (Akbar, 2017).

Sesuai dengan permasalahan yang diajukan di atas maka tujuan dari dilakukannya penelitian ini adalah untuk memberikan bukti empiris mengenai pengaruh variabel nature of industry dan ineffective monitoring terhadap fraud dalam penyajian laporan 
keuangan pada perusahaan sektor manufaktur yang terdaftar di Bursa Efek Indonesia periode 2013-2017.

Penelitian ini diharapkan dapat memberikan manfaat dalam meningkatkan pemahaman mengenai fraud yang dilakukan dalam lingkungan perusahaan dengan proksi nature of industry dan ineffective monitoring yang termasuk kategori opportunity dalam fraud triangle theory serta menambah pengetahuan akademisi mengenai fraud yang terjadi dalam penyajian laporan keuangan sehingga memperoleh gambaran antara kesesuaian di lapangan dan teoritis.

\section{REVIEW LITERATUR DAN PENGEMBANGAN HIPOTESIS}

\subsection{Konsep Kecurangan (Fraud)}

Menurut standar The Institute of Internal Auditors tahun 2013, fraud diartikan sebagai: "Any illegal act characterized by deceit, concealment, or violation of trust. These acts are not dependent upon the threat of violence or physical force. Frauds are perpetrated by parties and organizations to obtiain: money, property, orservices; to avoid payment or loss of services; or to secure personal or business advantage”. Dapat diartikan sebagai segala perbuatan yang dicirikan dengan pengelabuan atau pelanggran kepercayaan untuk mendapatkan uang, aset, jasa atau mencegah pembayaran atau kerugian atau untuk menjamin keuntungan/manfaat pribadi dan bisnis. Perbuatan ini tidak tergantung pada ancaman kekerasan oleh pelaku terhadap orang lain (Pusat Pengembangan Internal Audit, 2015).

\subsection{Fraud dalam Penyajian Laporan Keuangan (Financial Statement Fraud)}

Menurut Elder, et al (2011) fraud dalam penyajian laporan keuangan (financial statement fraud) merupakan salah saji atau penghapusan terhadap jumlah ataupun pengungkapan yang sengaja dilakukan dengan tujuan untuk mengelabui para penggunanya (Indriani dan Terzaghi, 2017).

Sedangkan dalam The Treadway Commission's Report of the National Commissionon Fraudulent Financial Reporting, (1987), fraud dalam penyajian laporan keuangan (financial statement fraud) diartikan sebagai kesengajaan atau kecerobohan dalam melakukan sesuatu atau tidak melakukan sesuatuyang seharusnya dilakukan yang menyebabkan laporan keuangan menjadi menyesatkansecara material. Fraud dalam penyajian laporan keuangan (financial statement fraud) merupakan upaya dalam 
menyajikan laporan keuangan tidak sesuai dengan prinsip akuntansi berterima umum. Kelalaian atau kesengajaan ini sifatnya material sehingga dapat mempengaruhi keputusan yang akan diambil oleh pihak yang berkepentingan. Sehingga akan menyesatkan para pengguna laporan keuangan (Herdiana dan Sari, 2018).

Penyebab fraud dalam penyajian laporan keuangan(financial statement fraud) umumnya 3 (tiga) hal sebagai berikut (Rini dan Achmad, 2012) :

1. Manipulasi, falsifikasi, alterasi atas catatan akuntansi dan dokumen pendukung atas laporan keuangan yang disajikan.

2. Salah penyajian (misrepresentation) atau kesalahan informasi yang signifikan dalam laporan keuangan.

3. Salah penerapan (misapplication) dari prinsip akuntansi yang berhubungan dengan jumlah, klasifikasi, penyajian (presentation) dan pengungkapan (disclosure).

\subsection{Nature of Industry}

Sifat industri (nature of industry) merupakan keadaan ideal suatu perusahaan dalam industri. Pada laporan keuangan terdapat akun-akun tertentu yang besarnya saldo ditentukan oleh perusahaan berdasarkan suatu estimasi, misalnya akun piutang tak tertagih dan akun persediaan usang (Herdiana dan Sari, 2018).

Sifat industri atau kegiatan entitas yang berpeluang melakukan pelaporan keuangan curang melalui (M.Tuanakotta, 2014):

- Transaksi dengan pihak terkait yang signifikan (significant related party transaction) yang tidak merupakan bagian normal bisnis entitas yang bersangkutan, atau dengan entitas terkait yang tidak diaudit atau diaudit KAP lain;

- Posisi keuangan yang begitu kuat atau kemampuan mendominasi industri atau sektor tertentu yang memungkinkan entitas memaksakan syarat atau kondisi tertentu kepada pemasok (suppliers) atau pelanggan (customers). Ini mungkin indikasi transaksi tidak wajar antar pihak yang tidak setara (inappropriate or non-arm's length transaction).

\subsection{Ineffective Monitoring}

Ineffective monitoring merupakan suatu keadaan yang menggambarkan lemah atau tidak efektifnya pengawasan perusahaan dalam memantau kinerja perusahaan. SAS No.99 menyatakan bahwa manajer berpeluang untuk melakukan kecurangan laporan 
keuangan jika tidak terdapat pengawasan yang efektif dalam perusahaan (Aprilia, 2017). Pengawasan yang tidak efektif akibat dari beberapa hal sebagai berikut (M.Tuanakotta, 2014):

- Dominasi manajemen oleh satu orang atau sekelompok kecil, tanpa pengendalian untuk mengimbanginya (compensating controls);

- Pengawasan oleh TCWG atas proses pelaporan keuangan dan pengendalian internal, tidak efektif.

\subsection{Pengembangan Hipotesis}

\subsubsection{Pengaruh Nature of Industry terhadap Fraud dalam Penyajian Laporan Keuangan}

Nature of industry merupakan suatu keadaan ideal industri dimana dalam laporan keuangan terdapat akun yang jumlah saldonya ditentukan oleh perusahaan. Dalam hal ini perusahaan sebagai pihak internal memiliki informasi lebih banyak, sehingga keadaan tersebut bisa dimanfaatkan perusahaan untuk mencari celah dalam melakukan kecurangan. Salah satu akun yang jumlah saldonya ditentukan oleh perusahaan adalah akun piutang tak tertagih dan akun persediaan usang. Penentuan jumlah saldo akunakun tersebut diperkirakan berdasarkan suatu estimasi. Dengan demikian manajer berkesempatan menggunakan akun piutang dan persediaan sebagai alat untuk memanipulasi laporan keuangan.

Hal lain perihal piutang dan persediaan adalah ketika perusahaan mengalami peningkatan pada kedua akun tersebut, karena dengan adanya peningkatan piutang dari tahun sebelumnya akan menjadi indikasi bahwa perputaran kas yang dimiliki perusahaan dalam keadaan tidak baik. Demikian pula dengan peningkatan persediaan, dalam keadaan tersebut kas yang dimiliki perusahaan mengendap dalam bentuk persediaan. Artinya banyaknya piutang dan persediaan perusahaan akan mengurangi jumlah kas yang dapat digunakan oleh perusahaan untuk kegiatan operasionalnya. Perputaran kas yang tidak baik dan terbatasnya kas akan mendorong manajemen untuk melakukan kecurangan dan memanipulasi laporan keuangan agar kinerja perusahaan tetap terlihat baik dimata investor atau pihak luar lainnya.

Penjelasan mengenai hubungan antara nature of industry dengan fraud dalam penyajian laporan keuangan juga diperkuat oleh penelitian terdahulu, seperti yang 
diungkapkan oleh Pardosi (2015) dimana hasil penelitiannya menunjukan bahwa nature of industry yang diproksikan dengan rasio perubahan persediaan (inventory) berpengaruh positif signifikan terhadap risiko kecurangan laporan keuangan.

Penelitian Nauval (2015) dengan judul analisis faktor-faktor yang berpengaruh terhadap kecenderungan financial statement fraud dalam perspektif fraud triangle. Populasi dalam penelitian ini adalah perusahaan sektor manufaktur yang terdaftar di Bursa Efek Indonesia selama periode 2009-2013. Hasil penelitiannya menunjukan nature of industry (inventory) berpengaruh positif signifikan terhadap kecenderungan financial statement fraud.

Lebih lanjut, penelitian yang dilakukan oleh Indriani dan Terzaghi (2017), Aulia (2018), Sihombing dan Rahardjo (2014) Fatmawati dan Sari (2017), Pasaribu dan Kharisma (2018), Pamungkas (2018) menujukkan hasil yang konsisten bahwa nature of industry (inventory dan receivable) berpengaruh positif signifikan terhadap kecenderungan financial statement fraud.

Dengan demikian peneliti dapat menduga bahwa nature of industry berpengaruh positif dan signifikan terhadap fraud dalam penyajian laporan keuangan. Dimana semakin tinggi peningkatan piutang dan persediaan, semakin tinggi pula kemungkinan terjadinya fraud dalam penyajian laporan keuangan.

\subsubsection{Pengaruh Inffective Monitoring terhadap Fraud dalam Penyajian Laporan Keuangan}

Ineffective monitoring merupakan suatu keadaan perusahaan dimana tidak memiliki pengawasan terhadap kinerja perusahaan yang efektif. Keadaan tersebut akan menjadi celah bagi manajemen untuk melakukan kecurangan. Terlebih lagi ketidakefektifan pengawasan ini terjadi karena adanya dominasi manajemen oleh satu orang atau sekelompok kecil. Sehingga membuka kesempatan manajer untuk memanipulasi laporan keuangan.

Upaya untuk meminimalkan kecurangan yang terjadi dalam perusahaan, salah satunya dengan melakukan mekanisme pengawasan yang baik. Hal tersebut dapat dilakukan dengan memberi kepercayaan pihak eksternal sebagai dewan komisaris untuk melakukan pengawasan secara independen. Pengawasan ini termasuk untuk mengendalikan tindakan oleh manajemen dalam menghindari kecurangan laporan keuangan. Karena dewan komisaris independen pada umumnya tidak memiliki 
hubungan dengan pihak agen yaitu manajemen dan pihak principal yaitu investor maupun pihak lainnya.

Penjelasan mengenai hubungan antara inffective monitoring dengan fraud dalam penyajian laporan keuangan juga diperkuat oleh penelitian terdahulu, seperti yang diungkapkan oleh Oktaviani, et al. (2014) yang menemukan bahwa ineffective monitoring berpengaruh positif signifikan terhadap financial statement fraud.

Hasil penelitian serupa ditunjukkan oleh Sulkiyah (2016), Aprilia (2017), Mardiani et al. (2017) yang menunjukan bahwa ineffective monitoring berpengaruh positif signifikan terhadap pendeteksian financial statement fraud.

Dengan demikian peneliti dapat menduga bahwa ineffective monitoring berpengaruh positif dan signifikan terhadap fraud dalam penyajian laporan keuangan. Dimana semakin kecil rasio dewan komisaris independen, maka semakin tinggi tingkat ketidakefektifan pengawasan dan semakin tinggi pula terjadi fraud dalam penyajian laporan keuangan.

\subsection{Model Analisis dan Hipotesis}

Berdasarkan kerangka teoritis yang telah diuraikan pada bagian sebelumnya, dapat dikemukakan model analisis seperti ditujukkan pada gambar berikut ini:

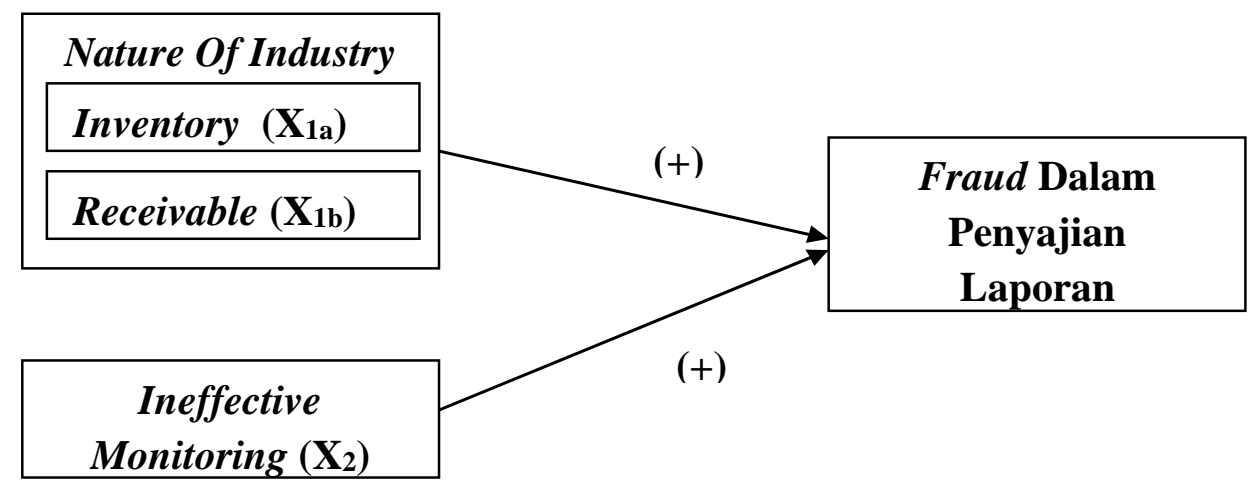

Gambar 1. Model Analisis

Hipotesis dalam penelitian ini adalah sebagai berikut:

H1a: Terdapat pengaruh positif dan signifikan dari nature of industry (inventory) terhadap fraud dalam penyajian laporan keuangan.

H1b: Terdapat pengaruh positif dan signifikan dari nature of industry (receivable) terhadap fraud dalam penyajian laporan keuangan. 
H2 : Terdapat pengaruh positif dan signifikan dari ineffective monitoring terhadap fraud dalam penyajian laporan keuangan.

\section{METODE PENELITIAN}

\subsection{Populasi dan Sampel}

Populasi dalam penelitian ini adalah seluruh perusahaan sektor manufaktur yang terdaftar di Bursa Efek Indonesia (BEI) selama periode 2013- 2017. Alasan dipilihnya perusahaan manufaktur pada penelitian ini, karena sektor manufaktur adalah sektor yang mempunyai jumlah emiten terbesar di BEI. Berdasarkan data survey ACFE menunjukkan bahwa persentase fraud dalam penyajian laporan keuangan paling tinggi terjadi pada sektor manufaktur yaitu sebesar 13,8\% (Susianti dan Yasa, 2015). Selain itu, perusahaan manufaktur rentan terhadap fraud, karena perusahaan manufaktur membutuhkan berbagai macam asumsi dan metode akuntansi dalam menangkap kejadian ekonomi perusahaannya (Akbar, 2017). Berdasarkan data yang diperoleh dari situs resmi Bursa Efek Indonesia (BEI) yaitu www.idx.co.id maka diperoleh populasi sebanyak 155 perusahaan. Teknik pengambilan sampel yang digunakan dalam penelitian ini adalah purposive sampling.

\subsection{Pengukuran Variabel}

\section{Nature Of Industry}

Herdiana dan Sari (2018) mendefinisikan nature of industry sebagai keadaan ideal suatu perusahaan dalam industri dimana dalam laporan keuangan terdapat akun-akun tertentu yang besarnya saldo ditentukan oleh perusahaan berdasarkan suatu estimasi. Summers dan Sweeney (1998) dalam Sihombing dan Rahardjo (2014) mencatat bahwa akun piutang dan persediaan memerlukan penilaian subjektif dalam memperkirakan tidak tertagihnya piutang dan obsolete inventory. Mereka menyarankan bahwa karena adanya penilaian subjektif dalam menentukan nilai dari akun tersebut, manajemen dapat menggunakan akun tersebut sebagai alat untuk manipulasi laporan keuangan (Pasaribu dan Kharisma, 2018). Maka penelitian ini menggunakan rasio perubahan persediaan dan rasio perubahan piutang sebagai proksi dari nature of industry. Variabel nature of industry diberi simbol INVENTORY dan RECEIVABLE. 


\section{Ineffective Monitoring}

Menurut Aprilia (2017) ineffective monitoring merupakan suatu keadaan yang menggambarkan lemah atau tidak efektifnya pengawasan perusahaan dalam memantau kinerja perusahaan. Lemahnya pengawasan yang efektif dalam memantau kinerja perusahan dapat dimanfaatkan pelaku fraud untukmelakukan fraud. Dewan komisaris independen dipercaya dapat meningkatkan efektifitas pengawasan karena tidak memiliki hubungan atau keterikatan secara langsung dengan perusahaan (Fatmawati dan Sari, 2017). Maka penelitian ini menggunakan rasio dewan komisaris independen sebagai proksi dari ineffective monitoring. Variabel ineffective monitoring diberi simbol BDOUT.

\section{Fraud dalam Penyajian Laporan Keuangan}

Fraud dalam penyajian laporan keuangan (financial statement fraud) pada penelitian ini diproksikan oleh earning overstatement (manipulasi laba) yang diukur menggunakan rasio Beneish M-Score Model. Beneish M-Score Model adalah suatu teknik analisis laporan keuangan yang dapat diterapkan untuk mendeteksi fraud laporan keuangan berupa manipulasi laba (earning overstatement). Beneish mengungkapkan bahwa pada umumnya manipulasi laba ditunjukkan dengan peningkatan atas pendapatan atau penurunan atas beban perusahaan secara signifikan dari suatu tahun (t) ke tahun sebelumnya (t-1). Berdasarkan hal tersebut, Beneish mengembangkan suatu rasio terkait dengan perubahan aset dan pertumbuhan penjualan yang dirumuskan dalam M-Score yaitu skor yang merefleksikan terjadinya manipulasi laba. Hasil penelitian Beneish menunjukkan bahwa terdapat hubungan antara manipulasi laba dengan beberapa rasio kunci tersebut dan telah diperoleh hasil perhitungan Beneish $M$-Score yang kekal (robust), dengan indikasi jika lebih dari -2,22 diklasifikasikan sebagai perusahaan fraud, bila kurang dari -2,22 diklasifikasikan sebagai perusahaan non-fraud. (Kartikasari dan Irianto, 2010).

Variabel fraud dalam penyajian laporan keuangan (financial statement fraud) ini adalah variabel dummy sehingga perusahaan yang diklasifikasikan sebagai perusahaan fraud diberi skor 1, artinya dikategorikan sebagai perusahaan yang melakukan kecurangan. Sedangkan perusahaan yang diklasifikasikan sebagai perusahaan non-fraud diberi skor 0, artinya dikategorikan sebagai perusahaan yang tidak melakukan 
kecurangan.

\subsection{Pengujian Hipotesis}

Pengujian hipotesis dalam pada penelitian ini menggunakan analisis regresi logistik (logistic regression). Pemilihan model ini didasarkan pada data yang digunakan dalam penelitian yang bersifat non metrik pada variabel dependen, sedangkan data variabel independennya bersifat metrik.

Pada penelitian ini prosedur regresi logistik yang dipakai yaitu regresi logistik biner. Regresi logistik biner (binary logistic regression) adalah regresi logistik dimana variabel dependennya berupa variabel dikotomi atau variabel biner. Contoh variabel dikotomi atau variabel biner adalah sukses-gagal, ya-tidak, benar-salah (Uyanto, 2009:258). Variabel dikatomi atau variabel biner pada penelitian ini adalah Fraud Non Fraud.

Adapun 2 model regresi logistik yang digunakan dalam penelitian ini adalah sebagai berikut :

$$
\begin{aligned}
& F S F_{1}=\mathrm{a}+\beta_{1} I N V E N T O R Y+\beta_{2} B D O U T+\mathrm{e} \\
& F S F_{2}=\mathrm{a}+\beta_{1} R E C E I V A B L E+\beta_{2} B D O U T+\mathrm{e}
\end{aligned}
$$

Keterangan:

$$
\begin{array}{ll}
\text { FSF } & =\text { Financial Statement Fraud } \\
\mathrm{a} & =\text { Konstanta } \\
\beta_{1}, \beta_{2} & =\text { Koefisien variabel } \\
\text { INVENTORY } & =\text { Nature Of Industry (Inventory) } \\
\text { RECEIVABLE } & =\text { Nature Of Industry (Receivable) } \\
\text { BDOUT } & =\text { Ineffective Monitoring } \\
\mathrm{e} & =\text { Error }
\end{array}
$$

\section{HASIL PENELITIAN DAN PEMBAHASAN}

Dalam penelitian ini sampel yang digunakan adalah perusahaan- perusahaan sektor manufaktur selama periode tahun 2013 sampai dengan 2017. Teknik pengambilan sampel yang digunakan dalam penelitian ini adalah teknik purposive sampling. Berdasarkan kriteria yang telah ditetapkan maka sampel yang didapat yaitu 
sebanyak 110 perusahaan dengan periode pengamatan selama 5 tahun, sehingga diperoleh 550 sampel amatan.

Setelah dilakukan pengolahan data didapat hasil bahwa ada 10 perusahaan yang memiliki data outlier. Peneliti memilih untuk mengeluarkan perusahaan tersebut dan data perusahaan tersebut tidak diolah kembali. Karena jika tetap diolah dikhawatirkan akan merusak hasil rata-rata keseluruhan data. Sehingga didapat sampel akhir sebanyak 100 perusahaan dengan 500 sampel amatan.

Tabel 2. Proses Seleksi Sampel

\begin{tabular}{|c|c|c|c|}
\hline No & Kriteria & $\begin{array}{c}\text { Sampel } \\
\text { Perusahaan }\end{array}$ & $\begin{array}{c}\text { Sampel } \\
\text { Amatan }\end{array}$ \\
\hline & Jumlah Populasi & 155 & 775 \\
\hline 1. & $\begin{array}{l}\text { Perusahaan sektor manufaktur yang tidak } \\
\text { terdaftar di Bursa Efek Indonesia (BEI) selama } \\
\text { periode penelitian yaitu tahun 2013-2017. }\end{array}$ & (19) & $(95)$ \\
\hline 2. & $\begin{array}{l}\text { Perusahaan sektor manufaktur yang delisting dari } \\
\text { Bursa Efek Indonesia (BEI) selama periode } \\
\text { penelitian yaitu tahun 2013-2017. }\end{array}$ & (3) & (15) \\
\hline 3. & $\begin{array}{l}\text { Perusahaan sektor manufaktur yang tidak } \\
\text { menyediakan laporan keuangan (audit) lengkap } \\
\text { untuk tahun yang berakhir } 31 \text { Desember per } \\
\text { masing-masing tahun penelitian yaitu 2013-2017. }\end{array}$ & (9) & $(45)$ \\
\hline 4. & $\begin{array}{l}\text { Perusahaan sektor manufaktur yang tidak } \\
\text { menyediakan annual report lengkap untuk tahun } \\
\text { yang berakhir } 31 \text { Desember per masing-masing } \\
\text { tahun penelitian yaitu 2013-2017, }\end{array}$ & (10) & $(50)$ \\
\hline 5. & $\begin{array}{l}\text { Perusahaan sektor manufaktur yang tidak } \\
\text { mempunyai kelengkapan data dalam laporan } \\
\text { keuangan dan annual report mengenai variabel- } \\
\text { variabel yang dibutuhkan dalam penelitian. }\end{array}$ & (4) & (20) \\
\hline 6. & Data outlier & (5) & $(50)$ \\
\hline & Jumlah Sampel & 100 & 500 \\
\hline
\end{tabular}




\subsection{Statistik Deskriptif}

Tabel 3. Panel A (Total Sampel)

\begin{tabular}{|l|r|r|r|r|r|}
\hline & \multicolumn{1}{|c|}{ N } & Minimum & Maximum & \multicolumn{1}{c|}{ Mean } & \multicolumn{1}{c|}{$\begin{array}{c}\text { Std. } \\
\text { Deviation }\end{array}$} \\
\hline FSF & 500 & $-7,1335$ & 4,7012 & $-2,287595$ &, 9016081 \\
INVENTORY & 500 &,- 3892 &, 5196 &, 006030 &, 0660194 \\
RECEIVABLE & 500 &,- 2604 &, 1674 &, 002171 &, 0389881 \\
BDOUT & 500 &, 1667 & 1,0000 &, 409761 &, 1141975 \\
Valid N (listwise) & 500 & & & & \\
\hline
\end{tabular}

Tabel 4. Panel B (Sub Sampel Fraud)

\begin{tabular}{|l|r|r|r|r|r|}
\hline & \multicolumn{1}{|c|}{ N } & Minimum & Maximum & \multicolumn{1}{c|}{ Mean } & \multicolumn{1}{c|}{$\begin{array}{c}\text { Std. } \\
\text { Deviation }\end{array}$} \\
\hline FSF & 206 & $-2,2165$ & 4,7012 & $-1,614293$ &, 7885743 \\
INVENTORY & 206 &,- 1497 &, 4661 &, 012464 &, 0620792 \\
RECEIVABLE & 206 &,- 2547 &, 1674 &, 013941 &, 0393421 \\
BDOUT & 206 &, 2000 &, 8000 &, 410521 &, 1134082 \\
Valid N (listwise) & 206 & & & & \\
\hline
\end{tabular}

Tabel 5. Panel C (Sub Sampel Non-Fraud)

\begin{tabular}{|l|r|r|r|r|r|}
\hline & N & Minimum & Maximum & Mean & $\begin{array}{c}\text { Std. } \\
\text { Deviation }\end{array}$ \\
\hline FSF & 294 & $-7,1335$ & $-2,2237$ & $-2,759364$ &, 6381882 \\
INVENTORY & 294 &,- 3892 &, 5196 &, 001523 &, 0683892 \\
RECEIVABLE & 294 &,- 2604 &, 0992 &,- 006076 &, 0366095 \\
BDOUT & 294 &, 1667 & 1,0000 &, 409206 &, 1149613 \\
Valid N (listwise) & 294 & & & & \\
\hline
\end{tabular}

Sumber: Output SPSS (data diolah, 2018).

Berdasarkan tabel 3 statistik deskriptif panel A, dapat diketahui bahwa jumlah sampel (n) adalah 500 sampel amatan yang diperoleh dari 100 sampel perusahaan sektor manufaktur dalam periode penelitian 5 tahun yaitu tahun 2013 sampai dengan 2017.

Fraud dalam penyajian laporan keuangan sebagai variabel dependen dalam penelitian ini memiliki nilai minimum sebesar -7,1335 dengan nilai maksimum sebesar 4,7012. Dan memiliki nilai rata-rata fraud dalam penyajian laporan keuangan sebesar 2,287595, berdasarkan ketentuan m-score menunjukan bahwa rata-rata perusahaan yang 
menjadi sampel dalam penelitian ini cenderung perusahaan yang diklasifikasikan sebagai perusahaan non-fraud dan informasi telah tersedia pada panel B dan C, bahwa pada panel C sub sampel non-fraud memiliki sampel yang lebih banyak yaitu 294 dibandingkan sub sampel fraud pada panel B. Sedangkan nilai standar deviasi untuk fraud dalam penyajian laporan keuangan yaitu sebesar 0,9016081 yang menunjukan bahwa standar deviasi lebih besar dibandingkan dengan rata-rata yaitu 0,9016081 > 2,287595 artinya data dari variabel fraud dalam penyajian laporan keuangan lebih bervariasi.

Inventory adalah kategori kedua dari variabel nature of industry sekaligus proksi kedua dalam penelitian ini yang memiliki nilai minimum sebesar -0,3892 dengan nilai maksimum sebesar 0,5196. Dan memiliki nilai rata-rata inventory sebesar 0,006030 yang mendekati nilai maksimum. Hal ini menunjukan bahwa rata-rata perusahaan yang menjadi sampel dalam penelitian ini cenderung mengalami kenaikan nilai persediaan dari penjualan sebesar 0,006030. Sedangkan nilai standar deviasi untuk inventory yaitu sebesar 0,0660194 yang menunjukan bahwa standar deviasi lebih besar dibandingkan dengan rata-rata yaitu 0,0660194 > 0,006030 artinya data variabel inventory lebih bervariasi.

Receivable adalah salah satu proksi dari varibel independen dalam penelitian ini. Receivable sebagai kategori variabel nature of industry memiliki nilai minimum sebesar $-0,2604$ dengan nilai maksimum sebesar 0,1674 . Dan memiliki nilai rata-rata receivable sebesar 0,002171 yang mendekati nilai maksimum. Hal ini menunjukan bahwa rata-rata perusahaan yang menjadi sampel dalam penelitian ini cenderung mengalami kenaikan nilai piutang dari penjualan sebesar 0,002171. Sedangkan nilai standar deviasi untuk receivable yaitu sebesar 0,0389881 yang menunjukan bahwa standar deviasi lebih besar dibandingkan dengan rata-rata yaitu 0,0389881 >0,002171 artinya data variabel receivable lebih bervariasi.

BDOUT merupakan proksi dari variabel independen yang kedua dalam penelitian ini yaitu ineffective monitoring. Memiliki nilai minimum sebesar 0,1667 dengan nilai maksimum sebesar 1,0000. Dan memiliki nilai rata-rata ineffective monitoring sebesar 0,409761, hal ini menunjukan bahwa rata-rata perusahaan yang menjadi sampel dalam penelitian ini cenderung memiliki porsi dewan komisaris independen sebesar 0,409761. Sedangkan nilai standar deviasi untuk BDOUT yaitu sebesar 0,1141975 yang menunjukan bahwa standar deviasi lebih kecil dibandingkan dengan rata-rata yaitu $0,1141975<0,409761$ artinya data variabel ineffective monitoring kurang bervariasi. 


\subsection{Kelayakan Model Regresi}

\subsubsection{Overall Fit Model Test}

Dalam penelitian ini overall fit model dinilai dengan chi square test. Penggunaan nilai chi square $\left(X^{2}\right)$ untuk keseluruhan model terhadap data digunakan dengan membandingkan nilai -2 log likehood awal atau hasil block number 0 (-2logL0) dengan -2 log likehood hasil block number 1 (-2logL1) sehingga nilai chi square $\left(X^{2}\right)$ didapat dari nilai $2 \log L 1-2 \log L 0$. Apabila terjadi penurunan, maka model tersebut menunjukkan regresi yang baik atau dengan kata lain model dihipotesiskan fit dengan data.

\section{Model 1 (INVENTORY, BDOUT dan FSF)}

Tabel 6. Likelihood Overall Fit Model I

\begin{tabular}{|l|l|l|}
\hline \multicolumn{2}{|c|}{ Iteration } & \multicolumn{1}{c|}{$\begin{array}{c}-2 \text { Log } \\
\text { likelihood }\end{array}$} \\
\hline \multirow{2}{*}{ Step 0 } & 1 & 677,580 \\
\cline { 2 - 3 } & 2 & 677,578 \\
\cline { 2 - 3 } & 3 & 677,578 \\
\hline Step 1 & 1 & 674,211 \\
\cline { 2 - 3 } & 2 & 674,200 \\
\cline { 2 - 3 } & 3 & 674,200 \\
\hline
\end{tabular}

Berdasarkan tabel 6 likehood overall fit model, pengujian block number 0 dimana pengujian dilakukan dengan memasukan 2 prediktor yaitu inventory sebagai proksi pertama dari variabel nature of industry dan bdout sebagai proksi dari variabel ineffective monitoring. Pengujian tersebut memperoleh -2 log likelihood awal sebesar 677,578. Kemudian, pengujian block number 1 diperoleh nilai -2 log likehood sebesar 674,200 . Hal ini menunjukan adanya penurunan nilai -2 log likehood sehingga dapat disimpulkan bahwa $\mathrm{H}_{0}$ diterima dan $\mathrm{H}_{1}$ ditolak, artinya model pertama yang dihipotesiskan fit dengan data atau model dinilai cukup mampu untuk menjelaskan hubungan variabel independen dengan variabel dependennya. 
Model 2 (RECEIVABLE, BDOUT dan FSF)

Tabel 7. Likelihood Overall Fit Model II

\begin{tabular}{|l|l|r|}
\hline \multicolumn{2}{|c|}{ Iteration } & \multicolumn{1}{c|}{$\begin{array}{c}-2 \text { Log } \\
\text { likelihood }\end{array}$} \\
\hline Step 0 & 1 & 677,580 \\
\cline { 2 - 3 } & 2 & 677,578 \\
\cline { 2 - 3 } & 3 & 677,578 \\
\hline Step 1 & 1 & 642,096 \\
\cline { 2 - 3 } & 2 & 639,385 \\
\cline { 2 - 3 } & 3 & 639,358 \\
\cline { 2 - 3 } & 4 & 639,358 \\
\cline { 2 - 3 } & 5 & 639,358 \\
\hline
\end{tabular}

Berdasarkan pada tabel 7 likehood overall fit model, pengujian block number 0 dimana pengujian dilakukan dengan memasukan 2 prediktor yaitu receivable sebagai proksi kedua dari variabel nature of industry dan bdout sebagai proksi dari variabel ineffective monitoring. Pengujian tersebut memperoleh -2 log likelihood awal sebesar 677,578. Kemudian, pengujian block number 1 diperoleh nilai -2 log likehood sebesar 639,358. Hal ini menunjukan adanya penurunan nilai -2 log likehood sehingga dapat disimpulkan bahwa $\mathrm{H}_{0}$ diterima dan $\mathrm{H}_{1}$ ditolak, artinya model kedua yang dihipotesiskan fit dengan data atau model dinilai cukup mampu untuk menjelaskan hubungan variabel independen dengan variabel dependennya.

\subsubsection{Goodness Of Fit Test}

Dalam penelitian ini uji kelayakan model menggunakan Hosmer and Lemeshow's Goodness of Fit Test. Uji tersebut bertujuan untuk menguji hipotesis nol bahwa data empiris cocok atau sesuai dengan model (tidak ada perbedaan antara model dengan data sehingga model dapat dikatakan fit).

\section{Model 1 (INVENTORY, BDOUT dan FSF)}

Tabel 8. Hosmer and Lemeshow Test $I$

\begin{tabular}{|l|c|c|c|}
\hline Step & Chi-square & df & Sig. \\
\hline 1 & 4,905 & 8 &, 768 \\
\hline
\end{tabular}

Berdasarkan tabel 8 hosmer and lemeshow test memperoleh nilai chi-square sebesar 4,905 dengan signifikansi sebesar 0,768. Hal ini menunjukan nilai signifikansi 
yang lebih besar dari 0,05 , sehingga dapat disimpulkan bahwa $\mathrm{H}_{0}$ diterima dan $\mathrm{H}_{1}$ ditolak, artinya model pertama yang dihipotesiskan dapat diterima karena cocok dengan data observasinya atau dapat dikatakan mampu memprediksi nilai data observasinya.

\section{Model 2 (RECEIVABLE, BDOUT dan FSF)}

Tabel 9. Hosmer and Lemeshow Test II

\begin{tabular}{|l|c|c|c|}
\hline Step & Chi-square & df & Sig. \\
\hline 1 & 12,160 & 8 &, 144 \\
\hline
\end{tabular}

Berdasarkan tabel 9 hosmer and lemeshow test memperoleh nilai chi-square sebesar 12,160 dengan signifikansi sebesar 0,144. Hal ini menunjukan nilai signifikansi yang lebih besar dari 0,05 , sehingga dapat disimpulkan bahwa $\mathrm{H}_{0}$ diterima dan $\mathrm{H}_{1}$ ditolak, artinya model kedua yang dihipotesiskan dapat diterima karena cocok dengan data observasinya atau dapat dikatakan mampu memprediksi nilai data observasinya.

\subsection{Pengujian Hipotesis}

\subsubsection{Omnibus Test Of Model Coefficient}

\section{Model 1 (INVENTORY, BDOUT dan FSF)}

Berdasarkan tabel 10 omnibus test of model coefficient dapat diketahui bahwa nilai chi-square atau penurunan atas nilai -2 log likehood sebesar 3,379 dengan nilai signifikansi 0,185. Nilai signifikansi yang didapat lebih besar dari taraf signifikansi atau $0,185>0,05$. Sesuai dengan ketentuan yang telah dijelaskan sebelumnya, maka dapat disimpulkan bahwa $\mathrm{H}_{0}$ diterima dan $\mathrm{H}_{1}$ ditolak, artinya secara simultan variabel nature of industry yang diproksikan oleh inventory $\left(\mathrm{X}_{1 \mathrm{a}}\right)$ dan ineffective monitoring $\left(\mathrm{X}_{2}\right)$ berpengaruh tidak signifikan terhadap fraud dalam penyajian laporan keuangan.

Tabel 10. Omnibus Test of Model Coefficient I

\begin{tabular}{|c|c|c|r|c|}
\hline \multicolumn{2}{|c|}{} & Chi-square & df & Sig. \\
\hline Step 1 & Step & 3,379 & 2 &, 185 \\
\cline { 3 - 5 } & Block & 3,379 & 2 &, 185 \\
\cline { 3 - 5 } & Model & 3,379 & 2 &, 185 \\
\hline
\end{tabular}


Model 2 (RECEIVABLE, BDOUT dan FSF)

Tabel 11. Omnibus Test of Model Coefficient II

\begin{tabular}{|l|l|r|r|r|}
\hline \multicolumn{2}{|c|}{} & \multicolumn{1}{c|}{ Chi-square } & \multicolumn{1}{c|}{ df } & \multicolumn{1}{c|}{ Sig. } \\
\hline Step 1 & Step & 38,220 & 2 &, 000 \\
\cline { 3 - 5 } & Block & 38,220 & 2 &, 000 \\
\cline { 3 - 5 } & Model & 38,220 & 2 &, 000 \\
\hline
\end{tabular}

Berdasarkan tabel 11 omnibus test of model coefficient dapat diketahui bahwa nilai chi-square atau penurunan atas nilai -2 log likehood sebesar 38,220 dengan nilai signifikansi 0,000. Nilai signifikansi yang didapat lebih kecil dari taraf signifikansi atau $0,000<0,05$. Sesuai dengan ketentuan yang telah dijelaskan sebelumnya, maka dapat disimpulan bahwa $\mathrm{H}_{0}$ ditolak dan $\mathrm{H}_{1}$ diterima, artinya secara simultan variabel nature of industry yang diproksikan oleh receivable $\left(\mathrm{X}_{1 \mathrm{~b}}\right)$ dan ineffective monitoring $\left(\mathrm{X}_{2}\right)$ berpengaruh signifikan terhadap fraud dalam penyajian laporan keuangan.

\subsubsection{Uji Wald}

Dalam penelitian ini, uji wald digunakan untuk menguji ada tidaknya pengaruh dari variabel independen terhadap variabel dependen secara parsial dengan membandingkan nilai signifikansi ( $\rho$-value) dengan alpha sebesar 5\%.

\section{Model 1 (INVENTORY, BDOUT dan FSF)}

Tabel 12. Uji Wald I

\begin{tabular}{|c|l|c|c|c|c|c|}
\hline \multicolumn{2}{|c|}{} & B & S.E. & Wald & df & Sig. \\
\hline \multirow{3}{*}{ Step 1a } & Nature of Industry (INV) & 2,573 & 1,441 & 3,188 & 1 &, 074 \\
\cline { 2 - 7 } & $\begin{array}{l}\text { Ineffective Monitoring } \\
\text { (BDOUT) }\end{array}$ &, 128 &, 798 &, 026 & 1 &, 872 \\
\cline { 2 - 7 } & Constant &,- 426 &, 340 & 1,568 & 1 &, 211 \\
\hline
\end{tabular}

Berdasarkan hasil olah data pada tabel 12 uji wald, maka persamaan untuk model pertama regresi logistik dalam penelitian ini adalah sebagai berikut:

$$
F S F_{1}=-0,426+2,573 I N V E N T O R Y+0,128 B D O U T+\mathrm{e}
$$

Dari tabel 12 dapat diketahui bahwa nilai signifikansi 0,211 artinya nilai signifikansi lebih besar dari taraf signifikansi yaitu 0,05 atau 0,211>0,05. Hal ini menunjukan bahwa hasil analisis regresi logistik secara parsial variabel independen yaitu nature of industry (inventory) dan ineffective monitoring berpengaruh tidak signifikan terhadap variabel dependen yaitu fraud dalam penyajian laporan keuangan. 
Nature of industry pada model ini yang diproksikan oleh inventory memiliki nilai wald sebesar 3,188 dengan tingkat signifikansi sebesar 0,074 >0,05. Sesuai dengan ketentuan yang telah dijelaskan sebelumnya, maka dapat disimpulan bahwa $\mathrm{H}_{0}$ diterima dan $\mathrm{H}_{1}$ ditolak, artinya secara parsial nature of industry yang diproksikan oleh inventory berpengaruh tidak signifikan terhadap fraud dalam penyajian laporan keuangan.

Variabel ineffective monitoring memiliki nilai wald sebesar 0,026 dengan tingkat signifikansi sebesar 0,872>0,05. Sesuai dengan ketentuan yang telah dijelaskan sebelumnya, maka dapat disimpulan bahwa $\mathrm{H}_{0}$ diterima dan $\mathrm{H}_{1}$ ditolak, artinya secara parsial ineffective monitoring berpengaruh tidak signifikan terhadap fraud dalam penyajian laporan keuangan.

\section{Model 2 (RECEIVABLE, BDOUT dan FSF)}

Berdasarkan hasil olah data pada tabel 13 uji wald, maka persamaan untuk model regresi logistik yang kedua dalam penelitian ini adalah sebagai berikut:

$$
F S F_{2}=-0,496+18,006 R E C E I V A B L E+0,152 B D O U T+\mathrm{e}
$$

Tabel 13. Uji Wald II

\begin{tabular}{|l|l|r|r|r|r|r|}
\hline \multicolumn{2}{|c|}{} & \multicolumn{1}{|c|}{ B } & \multicolumn{1}{c|}{ S.E. } & \multicolumn{1}{c|}{ Wald } & df & \multicolumn{1}{c|}{ Sig. } \\
\hline Step 1 $^{\mathrm{a}}$ & Nature of Industry (RCVB) & 18,006 & 3,324 & 29,349 & 1 &, 000 \\
\cline { 2 - 7 } & $\begin{array}{l}\text { Ineffective Monitoring } \\
\text { (BDOUT) }\end{array}$ &, 152 & 0,826 & 0,034 & 1 & 0,854 \\
\cline { 2 - 7 } & Constant &,- 496 &, 353 & 1,975 & 1 &, 160 \\
\hline
\end{tabular}

Dari tabel 13 dapat diketahui bahwa nilai signifikansi 0,160 artinya nilai signifikansi lebih besar dari taraf signifikansi yaitu 0,05 atau $0,160>0,05$. Hal ini menunjukan bahwa hasil analisis regresi logistik secara parsial variabel independen yaitu nature of industry (receivable) dan ineffective monitoring berpengaruh tidak signifikan terhadap variabel dependen yaitu fraud dalam penyajian laporan keuangan.

Nature of industry pada model ini yang diproksikan oleh receivable memiliki nilai wald sebesar 29,349 dengan tingkat signifikansi sebesar 0,000 $<0,05$. Sesuai dengan ketentuan yang telah dijelaskan sebelumnya, maka dapat disimpulan bahwa $\mathrm{H}_{0}$ ditolak dan $\mathrm{H}_{1}$ diterima, artinya secara parsial nature of industry yang diproksikan oleh receivable berpengaruhpositif dan signifikan terhadap fraud dalam penyajian laporan keuangan. 
Variabel ineffective monitoring memiliki nilai wald sebesar 0,034 dengan tingkat signifikansi sebesar $0,854>0,05$. Sesuai dengan ketentuan yang telah dijelaskan sebelumnya, maka dapat disimpulan bahwa $\mathrm{H}_{0}$ diterima dan $\mathrm{H}_{1}$ ditolak, artinya secara parsial ineffective monitoring berpengaruh tidak signifikan terhadap fraud dalam penyajian laporan keuangan.

\subsubsection{Koefisien Determinasi (Nagelkerke's $R$ Square)}

Koefisien determinasi menunjukan seberapa jauh kemampuan variabel independen dalam menerangkan variasi variabel dependen. Dalam penelitian ini koefisien determinasi yang digunakan adalah model Negelkerke's $R$ Square. Negelkerke's $R$ Square merupakan modifikasi dari koefisien Cox dan Snell untuk memastikan bahwa nilainya bervariasi dari 0 (nol) sampai 1 (satu). Hal ini dilakukan dengan cara membagi nilai Cox dan Snell's $\mathrm{R}^{2}$ dengan nilai maksimumnya.

\section{Model 1 (INVENTORY, BDOUT dan FSF)}

Tabel 14. Nagelkerke $R$ Square I

\begin{tabular}{|c|c|c|c|}
\hline Step & $\begin{array}{c}-2 \text { Log } \\
\text { likelihood }\end{array}$ & $\begin{array}{c}\text { Cox \& Snell } \\
\boldsymbol{R} \text { Square }\end{array}$ & $\begin{array}{c}\text { Nagelkerke } \boldsymbol{R} \\
\text { Square }\end{array}$ \\
\hline 1 & $674,200^{\mathrm{a}}$ &, 007 &, 009 \\
\hline
\end{tabular}

Berdasarkan tabel 14 nagelkerke $r$ square dapat diketahui bahwa besarnya koefisien determinasi (nagelkerke $r$ square) adalah 0,009. Artinya fraud dalam penyajian laporan keuangan dapat dijelaskan sebesar $0,9 \%$ oleh variabel nature of industry yang diproksikan oleh inventory $\left(\mathrm{X}_{1 \mathrm{a}}\right)$ dan variabel ineffective monitoring $\left(\mathrm{X}_{2}\right)$. Sedangkan sisanya $99,1 \%$ dijelaskan oleh variabel lain yang tidak diteliti dalam penelitian ini. Artinya bahwa variabel nature of industry yang diproksikan oleh inventory dan ineffective monitoring hanya mampu menimbulkan adanya variabel fraud dalam penyajian laporan keuangan sebesar 0,9 \%. Sedangkan sisanya 99,1 \% yang menimbulkan adanya fraud dalam penyajian laporan keuangan diakibatkan oleh faktor lain seperti kategori pada masing-masing variabel yang ada pada fraud triangle theory, fraud diamond theory dan fraud pentagon theory selain variabel opportunity. 
Model 2 (RECEIVABLE, BDOUT dan FSF)

Tabel 15 Nagelkerke $R$ Square II

\begin{tabular}{|c|c|c|c|}
\hline Step & $\begin{array}{c}\mathbf{- 2} \text { Log } \\
\text { likelihood }\end{array}$ & $\begin{array}{c}\text { Cox \& Snell } \\
\boldsymbol{R} \text { Square }\end{array}$ & $\begin{array}{c}\text { Nagelkerke } \boldsymbol{R} \\
\text { Square }\end{array}$ \\
\hline 1 & $639,358^{\mathrm{a}}$ &, 074 &, 099 \\
\hline
\end{tabular}

Berdasarkan tabel 15 nagelkerke $r$ square dapat diketahui bahwa besarnya koefisien determinasi (nagelkerke $r$ square) adalah 0,099. Artinya fraud dalam penyajian laporan keuangan dapat dijelaskan sebesar 9,9\% oleh variabel nature of industry yang diproksikan oleh receivable $\left(\mathrm{X}_{1 \mathrm{~b}}\right)$ dan variabel ineffective monitoring $\left(\mathrm{X}_{2}\right)$. Sedangkan sisanya $90,1 \%$ dijelaskan oleh variabel lain yang tidak diteliti dalam penelitian ini. Artinya bahwa variabel nature of industry yang diproksikan oleh receivable dan ineffective monitoring hanya mampu menimbulkan adanya variabel fraud dalam penyajian laporan keuangan sebesar 9,9\%. Sedangkan sisanya 90,1\% yang menimbulkan adanya fraud dalam penyajian laporan keuangan diakibatkan oleh faktor lain seperti kategori pada masing-masing variabel yang ada pada fraud triangle theory, fraud diamond theory dan fraud pentagon theory selain variabel opportunity.

\subsection{Pembahasan, Implikasi dan Keterbatasan}

\subsubsection{Pembahasan}

Inventory sebagai proksi pertama dari nature of industry tidak berhasil mendukung hipotesis $\mathrm{H}_{1 \mathrm{a}}$ yang menyatakan bahwa nature of industry (inventory) berpengaruh positif dan signifikan terhadap fraud dalam penyajian laporan keuangan karena hasil penelitian ini menunjukan bahwa naik atau turunnya dari nilai persediaan (inventory) tidak menjadi pemicu manajemen untuk melakukan fraud dalam penyajian laporan keuangan (financial statement fraud). Meskipun persediaan merupakan akun yang besar saldonya ditentukan oleh sebuah estimasi, hal tersebut tidak mampu membuktikan bahwa manajemen menggunakannya sebagai alat untuk melakukan kecurangan. Karena akun persediaan bukan hanya ditentukan oleh estimasi tetapi juga melalui perhitungan fisik. Selain itu, saat dilakukan audit atas laporan keuangan, auditor akan menyelaraskan antara saldo persediaan dalam laporan keuangan dengan bukti fisiknya. Artinya perusahaan akan lebih hatihati jika menggunakan akun ini sebagai alat untuk melakukan kecurangan. 
Hasil ini konsisten dengan hasil penelitian yang dilakukan oleh Utamaningsih (2015), Mawarni (2016), Rani (2016), Annisa et al (2016), Hafizah et al (2016) dan Rusianasari (2017) yang membuktikan bahwa nature of industry dengan proksi inventory berpengaruh tidak signifikan terhadap fraud dalam penyajian laporan keuangan. Sementara itu, penelitian ini tidak konsisten dengan hasil penelitian yang dilakukan oleh Nauval (2015), Pardosi (2015), Indiriani dan terzaghi (2017) serta Aulia (2018) yang membuktikan bahwa nature of industry dengan proksi inventory berpengaruh positif dan signifikan terhadap fraud dalam penyajian laporan keuangan.

Receivable sebagai proksi kedua dari nature of industry berhasil mendukung hipotesis $\mathrm{H}_{1 \mathrm{~b}}$ yang menyatakan bahwa nature of industry (receivable) berpengaruh positif dan signifikan terhadap fraud dalam penyajian laporan keuangan karena hasil penelitian ini menunjukan bahwa naik atau turunnya dari nilai piutang (receivable) akan menjadi pemicu manajemen untuk melakukan kecurangan. Peningkatan atas jumlah piutang dapat menjadi indikasi bahwa perputaran kas dalam perusahaan tidak baik. Banyaknya piutang akan mengakibatkan jumlah kas yang digunakan untuk melaksanakan kegiatan operasional perusahaan menjadi terbatas. Terbatasnya kas inilah yang akan mendorong manajemen untuk melakukan kecurangan. Namun, jika perusahaan mengalami penurunan atas piutang, dapat diindikasikan bahwa pembayaran dari debitur atau pihak yang berhutang relatif lancar, sehingga jumlah kas yang dapat digunakan untuk melakukan kegiatan operasional perusahaan tidak memiliki batasan karena perputaran kas dalam perusahaan tersebut baik. Dengan keadaan tersebut hanya kemungkinan kecil saja perusahaan menggunakan akun piutang sebagai alat kecurangan.

Hasil ini konsisten dengan hasil penelitian yang dilakukan oleh Yudhanti dan Suryandari (2017), Pasaribu dan Kharisma (2018), Sihombing dan Rahardjo (2014), Fatmawati dan Sari (2017) serta Pamungkas (2018) yang membuktikan bahwa nature of industry dengan receivable berpengaruh positif dan signifikan terhadap fraud dalam penyajian laporan keuangan. Sementara itu, penelitian ini tidak konsisten dengan hasil penelitian yang dilakukan oleh Ijudien (2018), Fahlevi (2015) dan Rahmayuni (2017) yang membuktikan bahwa nature of industry dengan proksi receivable berpengaruh tidak signifikan terhadap fraud dalam penyajian laporan keuangan.

Dalam penelitian ini ineffective monitoring di uji dalam dua persamaan regresi 
yaitu model pertama dan model kedua, dimana hasil dari kedua model tersebut tidak berhasil mendukung hipotesis $\mathrm{H}_{2}$ yang menyatakan bahwa ineffective monitoring berpengaruh positif dan signifikan terhadap fraud dalam penyajian laporan keuangan. Hasil tersebut menunjukan bahwa tinggi ataupun rendahnya tingkat ineffective monitoring tidak menjadi pemicu manajemen dalam melakukan fraud dalam penyajian laporan keuangan (financial statement fraud). Meskipun ketidakefektifan pengawasan yang ada dalam perusahaan membuat manajemen tidak diawasi dan semakin leluasa untuk melakukan kecurangan, hal tersebut tidak mampu membuktikan bahwa manajemen memanfaatkannya sebagai celah untuk melakukan kecurangan. Padahal diyakini bahwa keberadaan komisaris independen akan memberikan jaminan kepada pihak eksternal bahwa dalam perusahaan tersebut memiliki pengawasan yang independen dan objektif. Selanjutnya secara statistik, sampel dalam penelitian ini memiliki nilai rata-rata ineffective monitoring diatas aturan yang telah ditetapkan oleh Otoritas Jasa Keuangan yaitu peraturan nomor: 33/POJK.04/2014 sebesar 30\%. Diduga hal tersebut semata-mata hanya untuk mematuhi aturan yang berlaku saja, sehingga jumlah dewan komisaris independen perusahaan yang dijadikan sampel tidak menjadi suatu faktor yang signifikan dalam mencegah ataupun celah untuk melakukan kecurangan.

Hasil ini konsisten dengan hasil penelitian yang dilakukan oleh Nauval (2015), Rani (2016),Purba dan Putra (2017), Indriani dan Terzaghi (2017), Purba (2017) serta Pasaribu dan Kharisma (2018) yang membuktikan bahwa ineffective monitoring berpengaruh tidak signifikan terhadap fraud dalam penyajian laporan keuangan. Sementara itu, penelitian ini tidak konsisten dengan hasil penelitian yang dilakukan oleh Karyawati et al (2014), Sulkiyah (2016), Aprilia (2017) dan Mardiani et al (2017) yang membuktikan bahwa ineffective monitoring berpengaruh positif dan signifikan terhadap fraud dalam penyajian laporan keuangan.

\subsubsection{Implikasi}

Implikasi penelitian ini dapat dilihat dari hasil penelitian yang menunjukan bahwa nature of industry yang diproksikan oleh inventory berpengaruh tidak signifikan terhadap fraud dalam penyajian laporan keuangan. Sedangkan nature of industry yang diproksikan oleh receivable berpengaruh positif dan signifikan terhadap fraud dalam 
penyajian laporan keuangan. Perbedaan hasil disini dapat diartikan bahwa perusahaan yang dijadikan sampel dalam penelitian ini lebih mengandalkan akun receivable sebagai alat untuk melakukan kecurangan dibandingkan dengan inventory.

Hal ini disebabkan karena pada saat melakukan prosedur audit, auditor disyaratkan untuk memeriksa efektivitas metode klien dalam perhitungan persediaan dan kuantitas ataupun kondisi fisik persediaan. Sehingga, resiko terindikasi jika inventory digunakan sebagai alat kecurangan lebih besar. Oleh karena itu, bagi auditor harus memberi perhatian khusus terhadap akun receivable salah satunya dengan menelusuri jejak debitur secara lebih dalam, terlebih lagi yang berhubungan dengan piutang tak tertagih agar kemungkinan akun tersebut dijadikan sebagai alat kecurangan semakin kecil dan auditor harus lebih berhati- hati dalam memberikan opini audit terkait laporan keuangan untuk menghindari beberapa kecurangan yang sulit diprediksi. Sedangkan bagi investor harus lebih cermat dalam memilih perusahaan mana yang akan dijadikan tempat berinvenstasi.

Hasil penelitian yang menunjukan bahwa ineffective monitoring berpengaruh tidak signifikan terhadap fraud dalam penyajian laporan keuangan, hal tersebut dikarenakan adanya regulasi mengenai proporsi jumlah dewan komisaris independen, sehingga perusahaan memberikan kepercayaan kepada pihak luar semata-mata hanya untuk mematuhi aturan saja tanpa melihat fungsi yang sebenarnya. Maka dari itu, bagi perusahaan perlu adanya evaluasi atas fungsi dari dewan komisaris independen. Fungsi dari dewan komisaris independen harus dilakukan secara optimal guna mencegah upaya tindakan kecurangan.

\subsubsection{Keterbatasan}

Peneliti telah merancang penelitian ini, namun ada beberapa keterbatasan yang tidak terjangkau sehingga berpengaruh terhadap hasilnya:

1. Prediktor yang digunakan dalam penelitian ini hanya satu variabel yang termasuk dalam fraud triangle theory, fraud diamond theory dan fraud pentagon theory yaitu opportunity.

2. Variabel independen yang digunakan dalam penelitian ini hanya 2 kategori dari opportunity yaitu nature of industry dan ineffective monitoring. Sedangkan kategori struktur organisasi tidak diteliti dalam penelitian ini, karena kurangnya 
literatur dan rujukan yang didapat oleh peneliti, sehingga pemahaman peneliti atas kategori struktur organisasi sangat kurang. Hal tersebut berdampak pada hasil koefisien determinasi yang sangat kecil yaitu kurang dari $10 \%$.

\section{KESIMPULAN DAN SARAN}

Berdasarkan hasil penelitian yang dilakukan melalui berbagai tahap yaitu pengumpulan data, pengolahan data, analisis data dan interpretasi hasil analisis pengaruh nature of industry (inventory, receivable) dan ineffective monitoring terhadap fraud dalam penyajian laporan keuangan, maka dapat disimpulkan sebagai berikut :

1. Nature of industry (inventory) berpengaruh tidak signifikan terhadap fraud dalam penyajian laporan keuangan. Dengan kata lain, inventory tidak terbukti menjadi suatu faktor yang signifikan terhadap kejadian fraud dalam penyajian laporan keuangan. Hal ini menunjukan bahwa naik atau turunnya nilai persediaan (inventory) tidak menjadi pemicu ataupun celah manajemen dalam melakukan fraud dalam penyajian laporan keuangan. Karena jika dilihat dari penentuan jumlah saldo, akun persediaan dinilai bukan hanya berdasarkan estimasi saja tetapi berdasarkan perhitungan fisik dan pada saat prosedur audit, auditor akan menyelaraskan antara saldo persediaan dalam laporan keuangan dengan bukti fisiknya. Maka, perusahaan akan lebih hati-hati jika menggunakan akun ini sebagai alat untuk melakukan kecurangan.

2. Nature of industry (receivable) berpengaruh positif dan signifikan terhadap fraud dalam penyajian laporan keuangan. Dengan kata lain, receivable terbukti menjadi suatu faktor yang signifikan terhadap kejadian fraud dalam penyajian laporan keuangan dan lebih diandalkan (reliable) oleh perusahaan sebagai alat untuk melakukan kecurangan.Hal ini menunjukan bahwa naik atau turunnya dari nilai piutang (receivable) akan menjadi pemicu dan celah manajemen dalam melakukan kecurangan. Karena, banyaknya piutang mengindikasikan perputaran kas yang tidak baik dan mengakibatkan jumlah kas yang digunakan untuk melaksanakan kegiatan operasional perusahaan menjadi terbatas. Sehingga, terbatasnya kas akan mendorong manajemen untuk menutupi ketidak-baikan tersebut dengan cara melakukan fraud dalam penyajian laporan keuangannya.

3. Ineffective monitoring berpengaruh tidak signifikan terhadap fraud dalam penyajian laporan keuangan. Dengan kata lain, ineffective monitoring tidak terbukti menjadi suatu faktor yang signifikan terhadap kejadian fraud dalam penyajian laporan 
keuangan. Hal ini menunjukan bahwa tinggi ataupun rendahnya ineffective monitoring tidak menjadi pemicu manajemen dalam melakukan fraud dalam penyajian laporan keuangan. Karena, perusahaan memberikan kepercayaan kepada pihak luar sebagai dewan komisaris semata-mata untuk memenuhi regulasi saja. Tanpa melihat fungsi yang sebenarnya, padahal jika fungsi dewan komisaris independen dilakukan secara optimal akan mencegah terjadinya tindakan kecurangan, baik kecurangan (fraud) dalam penyajian laporan keuangan ataupun kecurangan dalam bentuk lainnya.

Berdasarkan keterbatasan yang peneliti telah uraikan terdapat beberapa saran untuk penelitian selanjutnya, yaitu bahwa dengan penelitian berikut dapat menambah prediktor lain yang termasuk dalam fraud triangle theory, fraud diamond theory dan fraud pentagon theory. Misalnya, kategori dalam variabel pressure, rationalization, capability, competence, dan arrogance.

\section{DAFTAR PUSTAKA}

Akbar, T. (2017). The Determination of Fraudulent Financial Reporting Causes by Using Pentagon Theory on Manufacturing Companies in Indonesia. International Journal of Business, Economics and Law, Vol. 14, 106-113.

Annisya, M., Lindrianasari, dan Asmaranti, Y. (2016). Pendeteksian Kecurangan Laporan Keuangan Menggunakan Fraud Diamond. Jurnal Bisnis dan Ekonomi (JBE), Vol. 23, 72-89.

Aprilia, R. (2017). Pengaruh Financial Stability, Personal Financial Need, Ineffective Monitoring, Change In Auditor Dan Change In Director Terhadap Financial Statement Fraud Dalam Perspektif Fraud Diamond. JOM Fekon, Vol. 4, 14721486.

Ardiyani, S., dan Utaminingsih, N. S. (2015). Analisis Determinan Financial Statement Melalui Pendekatan Fraud Triangle. Accounting Analysis Journal, Vol. 4, 1-10.

Audit, P. P. (2015). Fraud Risk and Control. Jakarta: Yayasan Pendidikan Internal Audit.

Audit, T. Y. (2008). Fraud Auditing. Jakarta: Yayasan Pendidikan Internal Audit.

Basuki, A. T., dan Prawoto, N. (2016). Analisis Regresi Dalam Penelitian

Ekonomi dan Bisnis. Jakarta: PT.Raja Grafindo Persada.

Bayagub, A., Zulfa, K., dan Mustoffa, A. F. (2018). Analisis Elemen-Elemen Fraud Pentagon Sebagai Determinan Fraudulent Financial Reporting. Isoquant Jurnal Ekonomi, Manajemen dan Akuntansi, Vol. 2, 1-11.

Fatmawati, E., dan Sari, R. P. (2017). Pengaruh Fraud Triangle Terhadap Fraudulent Financial Statement. Efektif. Jurnal Ekonomi dan Bisnis, Vol. 8, 1-18.

Hafizah, N., Wening, N., Respati, T., dan Chairina. (2016). Faktor-Faktor yang 
Mempengaruhi Kecurangan Laporan Keuangan Dengan Analisis Fraud Triangle. Jurnal Reviu Akuntansi dan Keuangan, Vol. 6, 811-822.

Herdiana, R., dan Sari, S. P. (2018). Analisis Fraud Diamond dalam Mendeteksi Financial Statement Fraud (Studi Empiris Perusahaan Manufaktur yang Terdaftar di Bursa Efek Indonesia Periode 2015-1017). Seminar Nasional dan Call For Paper III , 402-420.

Indriani, P., dan Terzaghi, M. T. (2017). Fraud Diamond Dalam Mendeteksi Kecurangan Laporan Keuangan. I-Finance, Vol. 3, 161-172.

Internal, K. O. (2004). Standar Profesi Audit Internal. Yayasan Pendidikan Internal Audit: Jakarta.

Iqbal, M., dan Murtanto. (2016). Analisa Pengaruh Faktor-Faktor Fraud Triangle Terhadap Kecurangan Laporan Keuangan Pada Perusahaan Property dan Real Estate yang Terdaftar di Bursa Efek Indonesia. Seminar Nasional Cendekiawan , Vol. 17.1-17.20.

Kartikasari, R. N., dan Irianto, G. (2010). Penerapan Model Beneish (1999) Dan Model Altman (2000) Dalam Pendeteksian Kecurangan Laporan Keuangan. Jurnal Akuntansi Multiparadigma, Vol. 1, 323-340.

Tuanakotta, T. (2010). Akuntansi Forensik \& Audit Investigatif. (2nd ed.). Jakarta: Salemba Empat.

Salemba Empat.

(2014). Mendeteksi Manipulasi Laporan Keuangan. Jakarta:

Mardiani, S., Sukarmanto, E., dan Maemunah, M. (2017). Pengaruh Fraud Diamond Terhadap Pendeteksian Financial Statement Fraud dengan Komite Audit Sebagai Variabel Moderasi. Prosiding Akuntansi , 476-484.

Nugraheni, N. K., dan Triatmoko, H. (2017). Analisis Faktor-Faktor yang Mempengaruhi Terjadinya Financial Statement Fraud: Perspektif Diamond Fraud Theory. Jurnal Akuntansi dan Auditing, Vol. 14, 118-143.

Oktaviani, E., Karyawati, G., dan Arsyad, N. (2014). Factors Affecting Financial Statement Fraud : Fraud Triangle Approach. 3rd Economics \& Business Research Festival, 1939-1955.

Pasaribu, R. B., dan Kharisma, A. (2018). Fraud Laporan Keuangan Dalam Perspektif Fraud Triangle. JRAK, Vol. 14, 85-102.

Purba, E. L., dan Putra, S. (2017). Analisis Fraud Diamond Dalam Mendeteksi Financial Statement Fraud : Studi Empiris Pada Perusahaan Manufaktur Yang Terdaftar Di Bursa Efek Indonesia. Jakpi, Vol. 5, 80-101.

Rahmayuni, S. (2018). Analisis Pengaruh Fraud Diamond terhadap Kecurangan Laporan Keuangan (Studi Empiris pada Perusahaan Manufaktur yang Terdaftar di BEI Tahun 2013-2016). E-Journa Akuntansil Unp, Vol. 6, 1-20.

Rini, V. Y., dan Achmad, T. (2012). Analisis Prediksi Potensi Risiko Fraudulent Financial Statement Melalui Fraud Score Model. Diponegoro Journal Of 
Accounting, Vol. 1, 1-15.

Sari, N. H., dan Ahmar, N. (2014). Revenue Discretionary Model Pengukuran Manajemen Laba: Berdasarkan Sektor Industri Manufaktur di Bursa Efek Indonesia. Jurnal Akuntansi dan Keuangan, Vol. 16, 43-51.

Sihombing, K. S., dan Rahardjo, S. N. (2014). Analisis Fraud Diamond Dalam Mendeteksi Financial Statement Fraud: Studi Empiris Pada Perusahaan Manufaktur yang Terdaftar di Bursa Efek Indonesia (BEI) Tahun 2010- 2012. Dipenegoro Journal Of Accounting, Vol. 03, 1-12.

Sulkiyah. (2016). Pengaruh Ineffective Monitoring Terhadap Financial Statement Fraud (Perusahaan Manufaktur Yang Terdaftar Di BEI). Journal Ilmiah Rinjani_Universitas Gunung Rinjani, Vol. 3, 130-140.

Suryadi, A., Rasuli, M., dan Indrawati, N. (2017). Pendeteksian Kecurangan Laporan Keuangan Dengan Metode Fraud Triangle dan SAS NO. 99. Jurnal Ekonomi, Vol. 25, 85-102.

Susianti, N. K., dan Yasa, I. B. (2015). Pengaruh Variabel Fraud Triangle Terhadap Financial Statement Fraud pada Perusahaan Manufaktur yang Terdaftar di Bursa Efek Indonesia. Jurnal Valid, Vol. 12, 417 - 428.

Utama, I. G., Ramantha, I. W., dan Badera, I. D. (2018). Analisis Faktor-Faktor Dalam Perspektif Fraud Triangle Sebagai Prediktor Fraudulent Financial Reporting. EJurnal Ekonomi dan Bisnis Universitas Udayana, Vol. 7, 251- 278.

Utomo, L. P. (2018). Kecurangan Dalam Laporan Keuangan "Menguji Teori Fraud Triangle". Jurnal Akuntansi dan Pajak, Vol. 19, 77-88.

Uyanto, S. S. (2009). Pedoman Analisis Data dengan SPSS. Yogyakarta: Graha Ilmu.

Warsidi, Pramuka, B. A., dan Suhartinah. (2018). Determinant Financial Statement Fraud: Perspective Theory of Fraud Diamond (Study Empiris pada Perusahaan Sektor Perbankan di Indonesia Tahun 2011-2015). Jurnal Ekonomi, Bisnis, dan Akuntansi (JEBA), Vol. 20.

Zahro, Y., Diana, N., dan Mawardi, M. C. (2018). Deteksi Financial Statement Fraud Dengan Analisis Fraud Triangle Pada Perusahaan Manufaktur Yang Terdaftar Di BEI. E-JRA, Vol. 07, 51-64.

\section{Sumber Dari Internet}

Finance, d. (2005). Bapepam Temukan Pelanggaran Serius di Great River. Dari: finance.detik.com. (diakses, 01/10/2018).

Finance, O. (2017). Laporan Keuangan Bermasalah, BEI Delisting Saham Inovisi Infracom. Dari: economy.okezone.com. (diakses, 01/10/2018).

Liputan6.com. (2015). Skandal Terungkap, CEO Toshiba Mundur. Dari: www.liputan6.com. (diakses, 01/10/2018).

Tempo.Co. (2003). Bapepam: Kasus Kimia Farma Merupakan Tindak Pidana.

Dari: bisnis.tempo.co. (diakses, 01/10/2018). www.idx.co.id 